\title{
POLA KONSUMSI GENERASI MILENIAL DALAM BELANJA ONLINE (E-COMMERCE) PADA MASA PANDEMIC COVID 19
}

\author{
Hilma Farhani,S.P.d . MM \\ Prof. Dr. Ir. Raihan, M.Si \\ Ratih Ayu Sekarini, MM \\ Faktultas Ekonomi Universitas Islam Jakarta \\ hilma@uid.ac.id \\ raihan17@gmail.com \\ ratihayus13@gmail.com
}

\begin{abstract}
ABSTRAK
Pada tahun 2020 sampai saat ini tahun 2021 adalah masa sejarah bagi seluruh dunia, hal iniididasari seluruh dunia sedang mengalami masa pandemicc covid 19. Pandemicc covid 19 yang terjadi secara global tentu saja berdampak pada berbagai sektor salah satunya sektor ekonomi. Penyakit Covid 19 telah menimbulkan economic shock baik secara perorangan, rumah tangga, perusahaan mikro \& makro kecil, menengah maupun besar, tidak hanya di Negara Indonesia saja namun bahkan mempengaruhi ekonomi negara lain. Hal ini berdampak mengubah pola aktivitas belanja yang biasanya masyarakat membeli kebutuhan langsung ke toko atau secara offline untuk membeli kebutuhan sehari-hari menjadi berbelanja secara online, pola konsumsi saat ini mulai merubah dari membeli barang dengan melihat atau mencoba secara langsung di toko/tempat menjadi membeli produk hanya berdasarkan informasi yang cukup tanpa mencoba/merasakan produk tersebut. Tujuan penelitian ini memberikan informasi tentang kondisi terjadi pada perubahan pola konsumsi pada perilaku konsumen pada saat pandemicc covid-19 terutama pada generasi milenial. Metode penelitian yang digunakan adalah metode kuantitatif. Hasil penelitian menunjukkan pola konsumsi pada indicator mencari informasi barang atau jasa secara online. Berdasarkan hasil penelitian disimpilkan bawah terdapat perubahan pada pola konsumsi generasi milinenal pada masa oandemi covid-19 pada indicator mencari informasi, menggunakan dan membeli pada jasa e-commers.
\end{abstract}

Keywords: Covid 19, Belanja Online, Pola Konsumsi, Generasi Milenial

\section{ABSTRACT}

In 2020 until now, 2021 is a historical period for the whole world, this is based on the fact that the whole world is experiencing a period of the COVID-19 pandemic. The global COVID-19 pandemic, of course, has an impact on various sectors, one of which is the economic sector. The Covid 19 disease has caused an economic shock for individuals, households, small, medium and large micro \& macro companies, not only in Indonesia but even affecting the economies of other countries. This has the impact of changing the pattern of shopping activities where people usually buy necessities directly to the store or offline to buy daily necessities to shopping online, current consumption patterns are starting to change from buying goods by seeing or trying directly in stores/places to buying product only based on sufficient information without trying / tasting the product. The purpose of this study is to provide information about the conditions that occur in changes in consumption patterns in consumer behavior during the COVID-19 pandemic, especially in the millennial generation. The research method used is a quantitative method. The results of the study show consumption patterns on the indicators of searching for information on goods or services online. Based on the results of the study, it is concluded that there is a change in the consumption pattern of the millennial generation during the covid-19 epidemic in the indicators of seeking information, using and buying on e-commers services.

Keywords: Covid 19, Online Shopping, Consumption Pattern, Millennial Generation 


\section{LATAR BELAKANG}

Tahun 2020 hingga tahun 2021 merupakan momentum besar di seluruh dunia dengan adanya peristiwa persebaran pandemicc Corona Virus Disease 2019 atau yang lebih dikenal dengan istilah Covid 19. Hadirnya Covid 19 yang merupakan sebuah virus mematikan yang saat ini masih belum ditemukan obatnya. Di Indonesia jumlah kasus yang semakin meningkat berdasarkan data terakhir yang diperoleh pada tanggal 17 agustus 2020 sudah 141.370 orang yang telah terkonfirmasi positif Covid 19 [1]. Pandemicc covid 19 ini menyebabkan adanya pergeseran dan perubahan pola komsumsi konsumen. Biasanya meskipun adanya penjualan online, namun konsumen tetap banyak membeli produk secara langsung ke toko. Namun dengan kondisi sekarang ini karena adanya pembatasan dan peraturan pemerintah untuk dirumah saja, pelaku usaha harus menyesuaikan diri dan mengkondisikan penjualan produk. Perlu adanya penyesuaian pelayanan dan pemasaran untuk dapat menarik konsumen.terbatasnya mobiilitas masyarakat untuk melakukan aktivitas atau kegiatan yang biasanya dilakukan sebelum pandemic.

Di masa pandemic ini pemakaian internet semakin meningkat hal ini disebabkan masyarakat beraktivitas dirumah saja, sehingga sangat besar dalam menunjang peningkatan online hingga memungkinkan persaingan dalam e-commerce. Pengusaha baik dalam barang dan jasa harus lebih menyiapkan langkah strategi untuk tetap dapat memenangkan pemilihan berdasarkan persepsi konsumen, sehingga sangat penting mengetahui perubahan keinginan mata komsumen. Pada generasi milenial ini terbiasa dan tidak lepas dengan dunia digital karena mereka telah dihadapkan dengan teknologi, seperti kemajuan internet, lahirnya smartphone, dan sebagainya. Perubahan pola konsumsi masyarakat khsusnya generasi mileneal yang lebih sering berbelanja secara online mengalami pertumbuhan cukup pesat dimasa pandemic covid-19, salah satunya yang paling terlihat dampaknya adala perubahan perilaku konsumsi akibat pendemic yaitu konsumen beralih ke paltfrom online yaiyu e-commers.

Berdasarkan laporan tinjauan dampak covid 192020 yang dijabarkan oleh BPS penjualan online pada masa pandemic ini malah melonjak tajam bila dibandingkan dengan penjualan di bulan Januari 2020. Pada bulan April 2020, penjualan tertinggi masih juga dipegang Makanan dan Minuman yang melonjak tajam 1070\% dari penjualan di bulan Januari 2020. Penjualan terendah masih produk olahraga yang sebesar $210 \%$ dari bulan Januari 2020 Selain Makanan dan Minuman serta peralatan Olahraga, beberapa penjualan yang meningkat juga terjadi pada alat kesehatan, peralatan komunikasi, kosmetik, perlengkapan rumah tangga, peralatan pendidikan, serta sandang [2]. Berdasarkan hasil BPS mengungkapkan pola belanja generasi milenial lebih banyak dilakukan dalam jaringan, karena mengikuti anjuran pemerintah untuk tetap dirumah selama pandemicc Covid 19 [3]. Berdasarkan telah diuraikan di atas, diperoleh state of the art terkait dengan perubahan perilakuk konsumsen dimasa pandemic covid-19. Melakukan penelitian mengenai informasi terkait perubaha pola konsumsi dalam belanja online pada generasi milenial selama pandemicc terjadi. Fenomena tersebut menarik perhatian peneleti utntuk menyelusuri lebih jauh tentang pola konsumsi dalam belanja online khsusnya pada generasi milenial. 


\section{TINJAUAN PUSTAKA}

Pada penelitian ini penulis ingin membantu para usaha yang berdampak langsung pada kondisi pandemicc Covid 19 yang semakin besar jumlah yang terindikasi positif dan membuat semakin ketat juga dalam aturan mengenai sosial distancing hal ini membuat aktivitas yang biasanya banyak diluar dengan kondisi sekarang dikurang frrekuensinya. Kebijakan yang pertama kali diumumkan oleh Presiden Joko Widodo, 2 Maret 2020 mengenai upaya pencegahan skala sebaran Covid-19, telah berimbas pada perubahan cara dan ritme beragam aktivitas, baik sosial kemasyarakatn, pelayanan public maupun kegiatan bisnis. Status Jakarta sebagai epicentrum Corona direspon oleh Pemda DKI melalui Instruksi Gubernur DKI Jakarta Nomor 16 Tahun 2020, tentang peningkatan kewaspadaan terhadap risiko penularan infeksi Covid19. Elisa M. Maffioli (2020) menjelaskan tingkat ukuran skala dan kecepatan cakupan penyebaran virus Covid-19 melebihi kasus wabah virus pada kejadian dekade sebelumnya. Penyakit Covid-19 menyebabkan respon masyarakat dunia sangat berbeda dengan kasus wabah virus yang pernah terjadi sebelumnya seperti virus H1N1 pada tahun 2009-2010, Virus Ebola tahun 2014 di Afrika Barat, atau Virus Zika Amerika Latin tahun 2015-2016, . Hal lain yang membedakan adalah status China yang menjadi titik awal sebaran Covid-19, merupakan Negara dengan kekuatan ekonomi nomor dua dunia sehingga berdampak luas pada interaksi bisnis dengan banyak negara mitra [4].

Dengan aturan pemerintah maka menjadi salah satu faktor perubahan besar pada kondisi sekarang dalam perilaku konsumen mengenai berbelanja yang biasanya masih pergi ke toko sekarang menjadi belanja online. Konsekuensi dari himbauan penutupan pusat perbelanjaan dan social distance adalah berkurangnya jumlah toko atau outlet yang dibuka, jam buka toko/outlet serta jumlah konsumen yang berkunjung. Hal ini berdampak pada tiga sisi, yaitu pertama bagi pelaku usaha usaha, konsumen, dan terakhir pemilik property seperti pemilik pertokoan/mall/plaza. Perilaku belanja online mengacu pada proses pencarian, pembelian, penggunaan dan pembuangan produk dan jasa melalui jasa e-commers. Maka pembelian secara online telah menjadi alternative pembelian barang atau jasa. Dimana konsumen tidak banyak beraktivitas diluar dan mengeluarkan banyak tenaga saat berbelanja online. Sebagian perusahaan yang memperhatikan inovasi produk serta ternad pasar berupaya menyesuaikan dengan platform online. Salah satu factor perilaku konsumen belanjan online adalah persepsi manfaat. Menurut Kim, Ferrin \& Rao persepsi manfaat merupakan keyakinan konsumen dalam sejauh mana ia akan menjadi lebih baik dari transaksi online melalui situs web terterntu atau applikasi platfrom ecommerce [5]. Kothler mengatakan "dampak perilaku konsumen dapat diukur dengan konsep AIDA, yaitu attention (perhatian), Interest (minat), Desire (keinginan) dan Action (tindakan)". [6] 


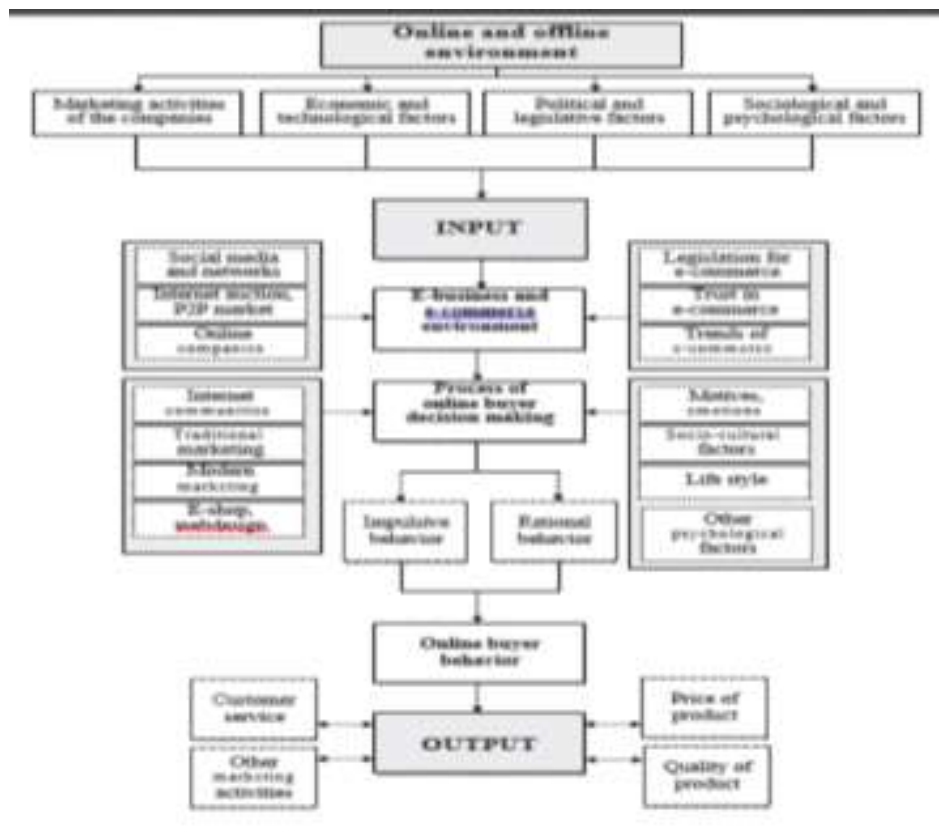

Gambar alur perilaku pembelian online

Perubahan perilaku konsumen tiap era perkembangan akan selalu berubah, dimana di era digital 4.0 ini semakin banyak generasi yang mudah mengakses dan berbelaja secara online. Fenomena pemakaian internet dan akses media sosial menjadi new style bagi masyarakat modern termasuk diberbagai generasi manusia di selueuh dunia. Salah satu gererasi yang banyak menggunakan akses digital dalam pencarian berbagai jenis kebutuhan informasi baik dalam hal mencari ilmu pengetahuan maupun dalam berbelanja yaitu generasi milenial. Generasi milenial dapat diartikan sekolompok orang yang memiliki karakteristik yang berbeda dengan yang lainnya utamanya adalah pada tahun lahirannya. Menurut penelitian yang dilakukan Prasad, Gupta \& Totala, Salah satu generasi sekarang dikenal dengan generasi millennials yang hidup di zaman perubahan komunikasi dan internet[7]. Menurut sumardinata \& Kris milenial merupakan generasi yang mulai dewasa pada era millennium abad ke -2 , generasi yang lahir pada tahun 1980-an sampai 2000-an, dimana usia mereka sedang berada di usia 18 sampai 30 tahun [8].
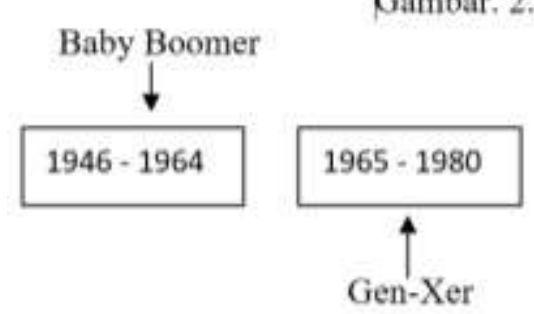

Gambar. 2.1 Phase Demograpic groups

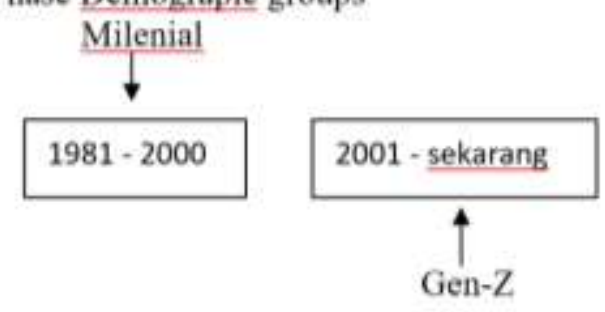

Dalam hal ini dapat peneliti katakan, bahwasannya dalam penelitian dosen pemula ini ialah pertama Penulis mengkaji dengan berdasarkan 1) Untuk merubah pola pelaku usaha dari pemasaran trandisonal ke model pemasaran dengan memanfaatkan digital teknologi informasi salah satunya penggunaan e-commerce dalam penjualan dan 
pemasaran produk usahanya. 2) Setelah memberikan informasi dan cara pemanfaatan digital dalam usaha kemudian membantu pelaku usaha memahami pola konsumsi mayarakat ke depannya. 3) Memperoleh data pola kosumsi pada generasi milenial terhadap minat belanja online (e-commerce). 4) Mengembangkan strategi pemasaran bisnis $e$-commerce pada generasi milinel.

Dari teori-teori di atas, maka yang dimaksud dengan perubahan pola konsumsi adalah perubahan tindakans eseorang/individu atau kelompok ketika mencari (searching), membeli produk (purchasing), menggunakan produk (using), mengevaluasi produk (evaluating) dan membuang lima produk (disposing).

\section{METODE}

Metode Penelitian pada prinsipnya adalah tata cara bagimana suatu penelitian akan dilaksanakan. Secara khusus, metode penelitian yang digunakan dalam penelitian ini adalah metode penelitian deskriptif. Nazir mengemukakan bahwa "penelitian deskriptif merupakan salah satu jenis metode penelitian yang dapat digunakan untuk mengumpulkan informasi aktual secara rinci mengenai fenomena yang ada".[9]

Penelitian ini dilakukan dengan survey terhadap generasi milenial khususnya pada mayarakat khususnya generasi milinel pada masa pandemicc covid 19 dengan pendekatan kuantitatif. Kriteria penelitian dengan meneliti diujikan. populasi atau sampe tertentu, pengumpulan data menggunakan instumen penelitian, analisis data bersifat kuantitatif/statistic.Penelitian dilaksanakan di wilayah Jakarta Timur. Menurut Malhotra menyatakan: "Populasi merupakan gabungan elemen yang memiliki serangkaian karakteristik yang serupa yang mencakup semesta kepentingan masalah riset pemasaran" [10]. Populasi dapat diartikan sebagai keseluruhan subjek-subjek penelitian yang dapat berupa orang, benda atau suatu hal yang didalamnya diperoleh atau dapat memberikan informasi data penelitian. Adapun populasi dalam penelitian ini adalah wilayah Jakarta Timur. Menurut Sugiyono sampel merupakan sebagian atau wakil dari populasi yang memiliki sifat dan karakter yang sama serta memenuhi populasi yang diselidiki.[11] Teknik yang digunakan dalam penelitian ini adalah purposive sampling. Metode yang digunakan adalah purposive sampling yaitu peneliti menggunakan pertimbangan sendiri secara sengaja dalam memilih anggota sampel yang dianggap dapat memberikan informasi yang diperlukan atau unit sampel yang sesuai dengan kriteria tertentu yang diinginkan peneliti yaitu generasi Milenial di kawasan Jakarta Timur yang masuk dalam generasi milenal berumur 18-37 tahun. Banyaknya sampel untuk penelitian berjumlah 124 responden.

Penelitian ini memperoleh data dari data primer dan data sekunder. Data primer menggunakan penelitian perpustakaan mereupakan suatu penyelidikan yang akan diadakan dalam rangka memperoleh fakta-fakta dan data-data melalui kajian pustaka dan dokumen yang relevan dengan masalah yang sedang diteliti.

Data sekunder menggunakan penelitian lapangan merupakan suatu penyelidikan yang diadakan untuk memperoleh fakta-fakta dan gejala-gejala yang ada dan mencari keterangan secara factual, melalui: pengamatan langsung dan angket kuesioner tentang pola konsumsi generasi milenial pada belanja online (e-commerce). Teknik pengumpulan data merupakan cara-cara yang digunakan untuk memperoleh data yang akan diperlukan dalam suatu penelitian. Teknik pengumpulan data yang digunakan untuk mendapat data dengan cara menggunakan angket/kuesioner yang diberikan kepada mahasiswa dalam generasi milenal berumur 18-37 tahun. Angket/kuesioner yang diberikan seperangkat 
pertanyaan yang bersifat tertutup, artinya mahasiswa tinggal memilih pilihan yang telah diberikan oleh peneliti.

Sugiyono menyatakan "Pertanyaan tertutup adalah pertanyaan yang mengharapkan jawaban singkat atau mengharapkan responden untuk memilih salah satu alternative jawaban dari setiap pertanyaan yang telah disediakan". Model angket yang digunakan dalam penelitian ini yaitu angket tertutup dengan skala Likert yang dimodifikasi. Jawaban setiap item instrumen yang menggunakan skala Likert akan diberi bobot dengan ukurang menggunnakan ukuran ordinal. Instrumen perubahan pola konsumsi diukur berdasarkan indikator-indikator berikut: (1) mencari informasi tentang produk dan jasa, (2) membeli produk, (3) menggunakan produk, dan (4) membuang produk disaat sebelum dan disaat pandemi Covid-19 terjadi. Data yang digunakan pada penelitian ini dianalisis dengan statistik deskriptif.

Desain penelitian

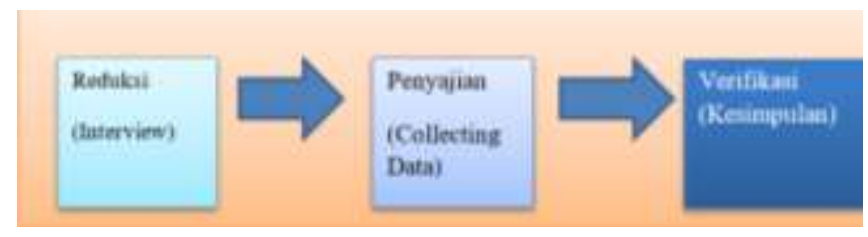

\section{HASIL DAN PEMBAHASAN}

Berdasarkan hasil survey menunjukkan bahwa masa pandemic covid-19 ternayat mengakibatkan perubahan pola konsumsi pada masyarakat terutama pada generasi milenial. Dimana dengan penerapan aturan stay at home menjadi factor utama keputusan belanja secara online di platform secara online yaitu e-commerce. Berikut ini tertera sejumlah responden dari usia 26 - 38 tahun dengan identitas yang berbeda.

Diagram 1 kategori responden
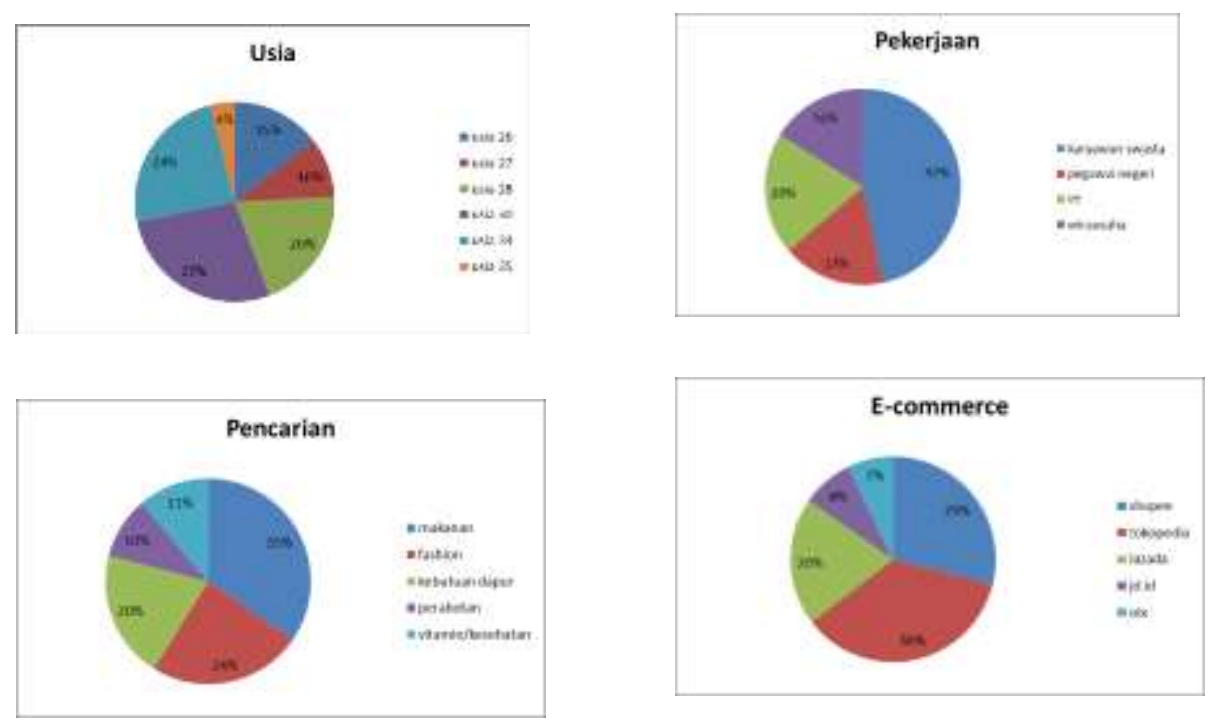

Berdasarkan diagram diatas maka generesi milinela dalam kategori usia 30 tahun yang lebih banyak menggunakan belanja online, dengan pekerjaan $47 \%$ karyawan swasta, 
$35 \%$ kebutuhan makanan yang sering dicari oleh konsumen serta $36 \%$ konsumen mencari kebutuhannya menggunakan e-commerce tokopedia.

Grafik 1. Persentase jawaban pertanyaan responden tentang varibel perubahan pola konsumsi

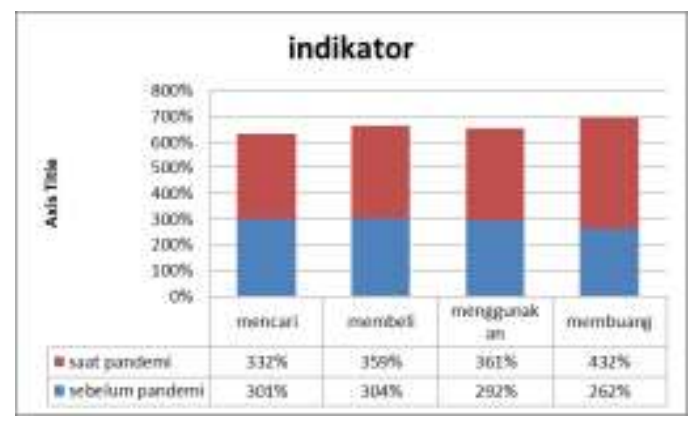

Grafik persentase skor pertanyaan di atas berdasarkan jawaban responden sebanyak 124 orang, pertanyaan indicator mencari varibel pola konsumsi responden khususnya generasi milenial yang menjawab pada saat belanja online selama pandemic. Hasil tersebut menunjukkan perubahan pola konsumsi generasi milenial dalam sebelum dan saat pandemic berlangsung pada indicator pencari informasi terkait barang dan jasa. Perubahan aktivitas konsumen dalam mencari informasi terkait tempat, barang atau jasa banyak dilakukan dimasa sebelum pandemic covid-19.

Pada indikator mencari sebelum pandemic pola konsumsi generasi milenial dalam mencari sekitar $301 \%$ namun saat pandemic mengalami peningkatan yaitu 332\%, dimana generasi melakukan pencarian kebutuhan yang akan dibeli menggunakan e-commerce yang sudah memiliki brand terkenal, hal ini menunjukkan bahwa perubahan pola konsumsi generasi milenial dalam konsumsi produk barang atau jasa merupakan perubahan kebiasaan yang sering dilakukan yang tadinya belanja langsung ke tempat/tokonya namun saat kondisi sekarang belanja secara online. Dampak dari penyakit covid-19 ini menyebabkan bergesernya aktivitas konsumen di dalam mencari barang dan jasa. Hal ini mengingatkan adanya factor eksternal selain dari kodnsi lingkungan dan kondisi aturan dari pemerintah.

Dalam membeli kebutuhan dgn kondisi pandemic mengalami peningkatan dimana setiap waktu mengalami fluktuatif dalam membeli barang atau menggunakan jasa yaitu sebesar $359 \%$ berbanding terbalik kegiatan sebelum pandemic. Perubahan aktivitas pembelian disini tidak menghilangkan aspek keseluruhan aspek pembelian. Karena kegiatan membeli mencakup semua hal yaitu setelah selesai melakukan pencarian, melakukan mengumpulan data, membandingkan harga dan kualitas produk, evaluasi informasi tentang produk tersebut lalu membeli di akhir dalam prosesnya. Transkasi pembelian saat belanja online juga dinyatakan lebih efisien dalam apsek membeli, karena dengan posisi di rumah saja kita bisa tetap membandingkan dan evaluasi produk sebelum membeli. Dengan belanja secara online menggunakan e-commerce juga memiliki dampak positif untuk mengurangi tersebarnya penyaki covid-19 lebih luas lagi. Berdasarkan hasil responden yang sering dibeli dalam jasa e-commerce pada pandemic adalah makanan yang sekitar $35 \%$ dari pada produk kebutuhan yang lainnya. 
Generasi mileneal tidak hanya membeli yang mengalami peningkatan namun juga dalam penggunaan barang yang telah dibeli secara online, dimana beberapa kali dalam pembelian generasi milinal dalam menggunakan bisa beberap kali melakukan pemesanan/pemakaianyanya yaitu sebesar $361 \%$, di saatn kondisi pandemic covid-19 terjadi konsumen dalam mengkonsumsi barang akan lebih bersikap hati-hati dalam halnya menjaga kebersihan barang yang dibeli.

Dimana penggunaan yang meningkatkan saat kondisi pandemic maka dalam aktivitas pembuangan produk pun juga mengalami peningkatan, aktivitas pembuangan yang secara benar seperti kemasan produk atau sisa produk itu sendiri banyak dilakukan konsumen saat kondisi pandemic covid-19 yaitu sebesar $432 \%$ berbanding terbalik saat sebelum pandemic. Perubahan pada konsumen dengan semakin sadar dengan kebersihan lingkungan tempat tinggal. Dengan menjaga kualitas lingkungan agar tetap sehat, secara otomatis akan memberikan pengaruh positif pada penggunanya. Hal ini juga menunjukkan bahwa generasi milenial sudah sadar dalam penggunaan yang baik untuk lingkungan dengan memiliah limbah domestic dan limbah infeksius.

\section{KESIMPULAN}

Berdasarkan hasil penelitian dan temuan diatas. Maka penelitian ini menyimpulkan selama pandemic covid-19 generasi mileneal mengalami perubahan dalam pola konsumsinya dimana perubahan tersebut meranah ke hal yang positif dan lebih efisien. Khususnya dalam mencari, membeli, menggunakan dan kegaiatan membuang dalam kebutuhannya. Hal ini juga menunjukkan bahwa generasi mileneal dalam digital 4.0 sudah mengalami peningkatan dalam teknologi, yang dimana penggunaan teknologi tidak hanya memberi informasi namun juga bisa dalam hal proses transaksi jual beli 


\section{DAFTAR PUSTAKA}

Kawalcovid19.id

https://nasional.kontan.co.id/news/bps-catat-penjualan-online-melonjak-tajam-selamapandemic-corona

https://ekonomi.bisnis.com/read/20200603/12/1247992/pandemic-covid-19-survei-bpstren-belanja-online-naik-mayoritas-milenial-perempuan

Elisa M. Maffioli, 2020, How is the World Responding to the 2019 Coronavirus Disease Compared with the 2014 West African Ebola Epidemic? The Importance of China as a Player in the Global Economy, Am. J. Trop. Med. Hyg., 00(0), p pp. 1-2 doi:10.4269/ajtmh.20-0135

Kim, D. J., Ferrin, D. L., \& Rao, H. R. (2008). A trust - based consumer decision making model in electronic commerce: The role of trust, perceived risk, and their antecedents. Decision Support Systems, 44(2), 544564. https://doi.org/10.1016/j.dss.2007.07.00.

Kotler, P. (2004). Manajemen Pemasaran, Jakarta : PT Indeks

Deni Ansari Harahap, 2018, Perilaku Belanjan Online di Indonesia, Jurnal Riset Manajemen Sains Indonesia (JRMSI) | Vol 9, No. 2, 2018 e- ISSN: 2301 8313http://doi.org/10.21009/JRMSI.

Prasad, S., Gupta, I. C., \& Totala, N. K. (2017). Social media usage, electronic word of mouth and purchase-decision involvement. Asia-Pacific Journal of Business Administration, Vol. 9.

Triana Anggraini Faradiah, Hanifa Sri nuryani (2019). Keputusan Pembelian di online shop pada pengguna media Sosial (studi kasus generasi Milinelas). Jurnal Manajemen dan bisnis vol 2 no 12019. Jurnal uts.ac.id

Nazir, Moh. (2014). Metode Penelitian. Bogor: Ghalia Indonesia.

Malhotra, Naresh, K. (2017). Riset Pemasaran Pendekatan Terapan. Jakarta: Indeks. 